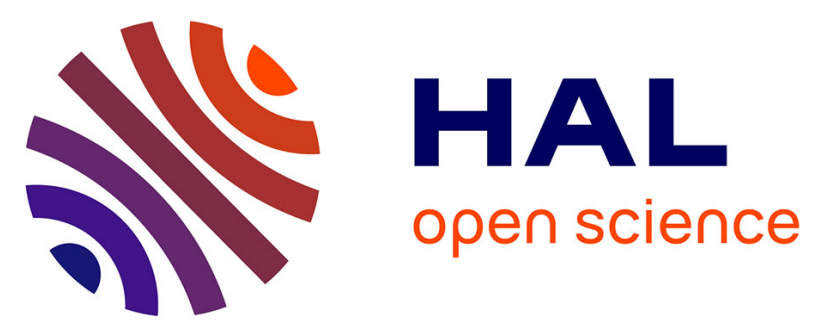

\title{
ON THE OPTIMIZATION OF THE MICROSTRUCTURE AND THE ADHERENCE OF TiC/TiN COATINGS DEPOSITED AT MODERATE TEMPERATURE FOR MILLING APPLICATIONS
}

\author{
B. Drouin, L. Vandenbulcke, J. Piton, R. Herbin
}

\section{To cite this version:}

B. Drouin, L. Vandenbulcke, J. Piton, R. Herbin. ON THE OPTIMIZATION OF THE MICROSTRUCTURE AND THE ADHERENCE OF TiC/TiN COATINGS DEPOSITED AT MODERATE TEMPERATURE FOR MILLING APPLICATIONS. Journal de Physique IV Proceedings, 1991, 02 (C2), pp.C2-633-C2-640. 10.1051/jp4:1991276 . jpa-00249866

\section{HAL Id: jpa-00249866 https://hal.science/jpa-00249866}

Submitted on 1 Jan 1991

HAL is a multi-disciplinary open access archive for the deposit and dissemination of scientific research documents, whether they are published or not. The documents may come from teaching and research institutions in France or abroad, or from public or private research centers.
L'archive ouverte pluridisciplinaire HAL, est destinée au dépôt et à la diffusion de documents scientifiques de niveau recherche, publiés ou non, émanant des établissements d'enseignement et de recherche français ou étrangers, des laboratoires publics ou privés. 
Colloque C2, suppl. au Journal de Physique II, Vo1. 1, septembre 1991

ON THE OPTIMIZATION OF THE MICROSTRUCTURE AND THE ADHERENCE OF TIC/TIN COATINGS DEPOSITED AT MODERATE TEMPERATURE FOR MILLING APPLICATIONS

\author{
B. DROUIN, L. VANDENBULCKE, J.P. PITON and R. HERBIN \\ CRCCHT-CNRS, F-45071, Orléans cedex 2, France
}

\begin{abstract}
Titanium carbide and nitride coatings can be deposited at a moderate temperature of about $850^{\circ} \mathrm{C}$, respectively from butane and nitrogen and a mixture of titanium chlorides containing high concentrations of the subchlorides which are generated in-situ by the prereduction of $\mathrm{TiCl}_{4}$ by $\mathrm{Ti}$ metal. Under optimized deposition conditions, a very hard titanium carbide with a polynucleated fine grained structure is obtained which is maintained inside the entire layer. However all conditions which lead to high microhardness do not allow the preservation of a good adherence with the cemented carbide substrate. The process was therefore optimized from a morphological, structural, and solid composition study and also from the point of view of microhardness and scratch test measurements. Titanium nitride deposition was also optimized from a composition, morphological and microhardness study but also in terms of surface roughness and friction coefficient.The value of this process which allows one both to obtain an improved bilayer coating and to maintain a high toughness of the substrate is demonstrated when compared to the performance of a classical TiC/TiN coating deposited at about $1000^{\circ} \mathrm{C}$ using the same severe conditions of a milling test.
\end{abstract}

\title{
1 - INTRODUCTION :
}

It was shown previously that the kinetic limitations of a $\mathrm{TiCl}_{4}-\mathrm{CH}_{4}-\mathrm{H}_{2}$ reactant gas mixture employed at moderate temperature to deposit titanium carbide could be overcome when butane was used together with subchlorides of global composition approximating to $\mathrm{TiCl}_{3}$. produced by the in-situ prereduction of titanium tetrachloride by titanium metal [1]. From a comparison with a thermodynamic study, it was shown that the deposition conditions deviated from equilibrium. The supersaturation at the deposition surface together with the moderate temperature of $850^{\circ} \mathrm{C}$ generally led to a grain refinement with a polynucleated structure in the whole layer [2]. However the properties of the coating and its adherence depended on the deposition conditions. Their optimization will be specifically reported here.

Titanium nitride was also deposited under the same conditions of in-situ formation of the titanium subchlorides and reaction with nitrogen at the same temperature of $850^{\circ} \mathrm{C}$. The importance of the reaction of disproportionation was also reported [3-4]. The importance of the composition and morphology of these nitride layers will be pointed out. 
Finally a metallographic investigation of the bilayer TiC/TiN coating on cemented carbides will be reported together with a toughness test which will be compared to the results obtained with the same bilayer coating deposited under the conventional CVD temperature of $1000^{\circ} \mathrm{C}$.

\section{2 - OPTIMIZATION OF THE TITANIUM CARBIDE DEPOSITION :}

\section{2 - 1. STEEL SUBSTRATES :}

The optimization of the titanium carbide deposition conditions was first carried out on steel substrates. It was pointed out previously that the deposition of free carbon led to a high incorporation of chlorine which could reach 5 at\% [5] with poor crystallization as observed from the X-ray diffraction patterns. However when no free carbon was included, under some conditions a non-negligible incorporation of chlorine up to about 2 at $\%$ can also occur. Only a small change of the lattice parameter was observed for a constant $\mathrm{C} / \mathrm{Ti}$ ratio but the incorporation of chlorine led to a broadening of the (111) X-ray peak of titanium carbide. The microhardness of the titanium carbide layers is strongly influenced by this incorporation of chlorine for concentrations largers than 0.5 at\% (Figure 1) [5]. The deposition conditions can also influence the crystalline orientation of the deposits and consequently, in some cases, their microhardness as shown for example by Williams et al [6]. In fact high microhardnesses can be related to conditions where all the texture coefficients approach one if no other important influence arises such as the incorporation of free carbon, of chlorine or an significant porosity of the deposit. It was shown previously [2-3] that these conditions correspond to a mechanism principally controlled by the disproportionation of the titanium subchlorides which leads to a polynucleated structure without preferred orientation. As the deposition rate is relatively high under these conditions (greater than $0.7 \times 10^{-6} \mathrm{~g} \cdot \mathrm{cm}^{-2} \cdot \mathrm{s}^{-1}$ ), it is also important to examine the nucleation as this also controls the grain size.

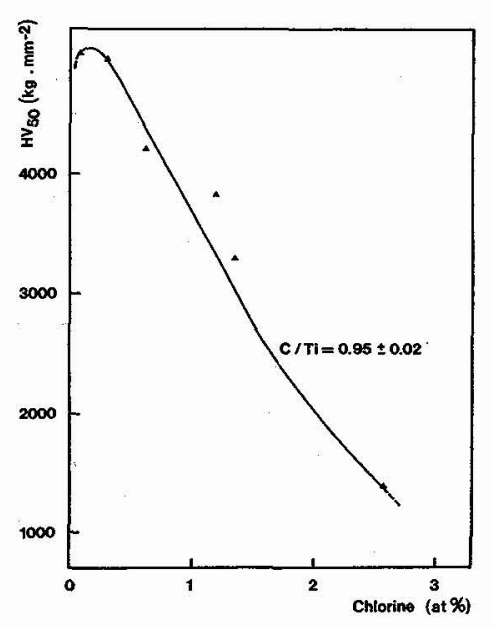

Fig. 1 : Influence of the chlorine content on the microhardness of the coatings at constant $\mathrm{C} / \mathrm{Ti}$ ratio.
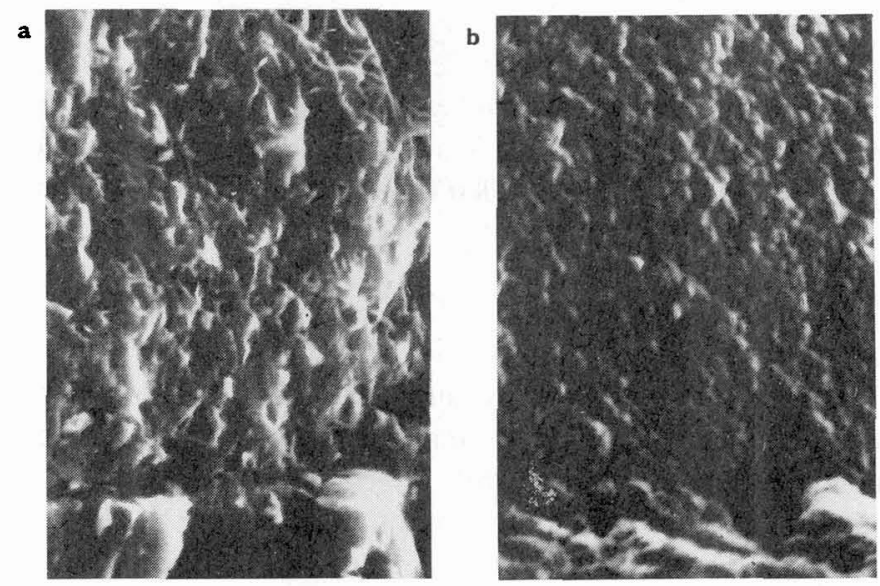

Fig. 2 : a) Fractured cross-section showing a "needle-like" and porous structure $\left(\mathrm{X}_{\mathrm{TiCl}_{3} \mathrm{O}}^{\mathrm{O}}=2.8 \times 10^{-2}, 4 \mathrm{X}_{\mathrm{C}_{4} \mathrm{H}_{10}}^{0}=7.7 \times 10^{-2}\right.$, $\mathrm{T}=850^{\circ} \mathrm{C}, \mathrm{P}=5.33 \times 10^{3} \mathrm{~Pa}, \mathrm{Hv}_{50}=1150 \pm 50 \mathrm{~kg} \cdot \mathrm{mm}^{-2}$ ). b) Fractured cross-section of a dense fine-grained deposit $\left(\mathrm{X}^{0}{ }_{\mathrm{TiCl}_{3}}=1.5 \times 10^{-2}, 4 \mathrm{X}^{0}{ }_{\mathrm{C}_{4} \mathrm{H}_{10}}=5.8 \times 10^{-2}, \mathrm{~T}=850^{\circ} \mathrm{C}\right.$, $P=5.33 \times 10^{3} \mathrm{~Pa}, \mathrm{Hv}_{50}=4950 \pm 270 \mathrm{~kg} \cdot \mathrm{mm}^{-2}$ ).

The deposition temperature of $850^{\circ} \mathrm{C}$ is sufficiently moderate to produce a grain refinement in most conditions of deposition. Except at high concentrations of titanium chlorides $\left(\mathrm{X}_{T_{1}}^{0} \geq 0.025\right)$ 
and butane $\left(\mathrm{X}_{\mathrm{C}}^{0} \geq 0.05\right)$ where fractured cross-sections show a "needle-like" and porous morphology (Fig. 2a), the morphological grain size appears always equal or lower than $2000 \AA$. Moreover in the favorable conditions indicated above where the disproportionation appears to control the deposition, a very dense fine-grained deposit is obtained as shown in Figure $2 b$. The corresponding measured microhardness is very high, of the order of $5000 \mathrm{~kg} \cdot \mathrm{mm}^{-2}$ under $50 \mathrm{~g} \mathrm{load}$, since all the other parameters $(\mathrm{C} / \mathrm{Ti}$ and $\mathrm{Cl}$ incorporation) are also optimized under these conditions. Figure 3 shows how these optimized conditions of high microhardness are obtained from the inlet $\left(\mathrm{X}_{\mathrm{T}}^{0}, \mathrm{X}_{\mathrm{C}}^{0}\right)$ composition of the gaseous phase when the ratio $\mathrm{X}_{\mathrm{Ti}}^{0} / \mathrm{X}_{\mathrm{C}}^{0} \simeq 1 / 4$. However these high microhardnesses are measured on coatings deposited on steel substrates and the influence of compressive stresses cannot be neglected. The real characteristics of the deposits will be better approached when measured on cemented carbide substrates.

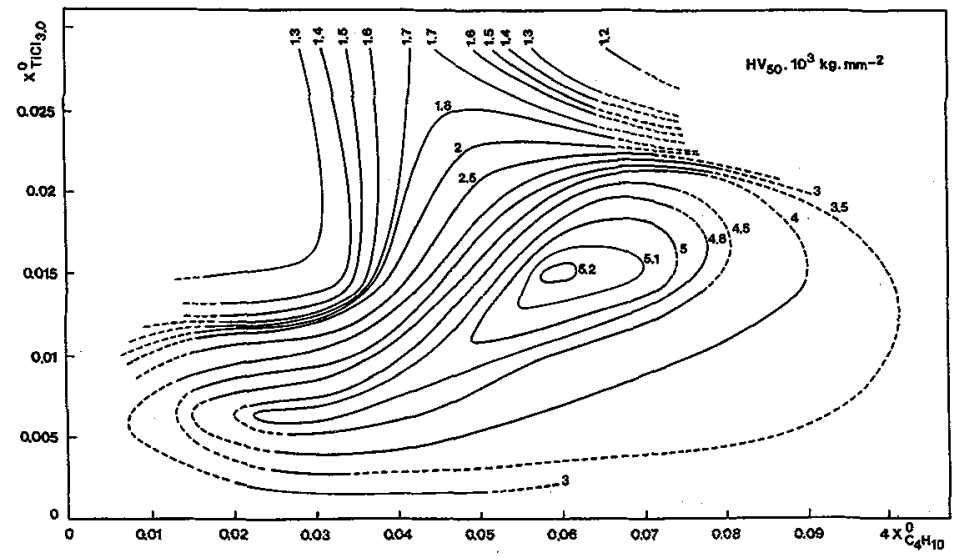

Fig. 3 : Variations of the microhardness as a function of the inlet gas composition $\left(\mathrm{T}=850^{\circ} \mathrm{C}, \mathrm{P}=5.33 \times 10^{3} \mathrm{~Pa}\right)$.

\section{2 - 2. CEMENTED CARBIDE SUBSTRATES :}

In the previous study a steel with a composition $2.2 \mathrm{C}-14 \mathrm{Cr}-0.7 \mathrm{Si}-0.45 \mathrm{Mn}-0.5 \mathrm{~W}$ was used as a substrate. Various cemented carbides have been utilized to examine the influence of the substrate. In spite of the moderate deposition temperature employed, the deposition rate turned out to be a function of the substrate material. It was nearly equal for the steel and the pure $\mathrm{WC} / \mathrm{Co}$ substrates but lower for cemented carbides containing cubic carbides ( $\mathrm{TiC}, \mathrm{TaC}, \mathrm{NbC}$ ) in addition to WC (Figure 4).

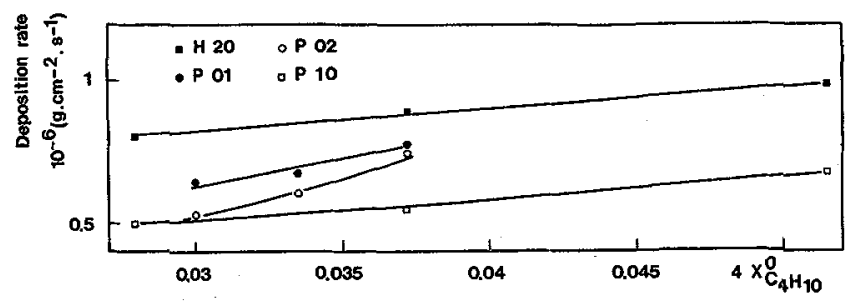

Fig. 4 : Deposition rate of titanium carbide on different cemented carbides as a function of the inlet butane concentration $\left(\mathrm{X}_{\mathrm{T}_{\mathrm{iCl}} \mathrm{C}_{3}}=7.5 \times 10^{-3}, \mathrm{~T}=850^{\circ} \mathrm{C}, \mathrm{P}=5.33 \times 10^{3} \mathrm{~Pa}\right)$.

This well-known phenomenon has been reported by various authors (7-9) for the conventional high-temperature process (appr $1000 \mathrm{C}$ ) and it is attributed to carbon diffusing from 
the substrate into the coating. However, under the deposition conditions employed here, the diffusion of carbon was sufficiently limited, especially for the P01, P02 and P10 carbides to avoid any formation of eta phase.

Figure 5 shows the variations of the $\mathrm{C} / \mathrm{Ti}$, chlorine content, deposition rate and microhardness for the P01 and P02 carbides substrates. These depositions were made under the optimized conditions for steel substrates with the $\mathrm{X}_{{ }^{0} j} / \mathrm{X}_{\mathrm{C}}{ }_{\mathrm{C}}$ inlet gas phase ratio being $1 / 4$. These variations are relatively smooth except for the deposition rate which can be multiplied by a factor 2. The $\mathrm{Cl}$ content is equal to or smaller than 0.5 at $\%$, the $\mathrm{C} / \mathrm{Ti}$ always approaches 1 and the microhardness is maintained in the range $3800-4200 \mathrm{~kg} \cdot \mathrm{mm}^{-2}$.
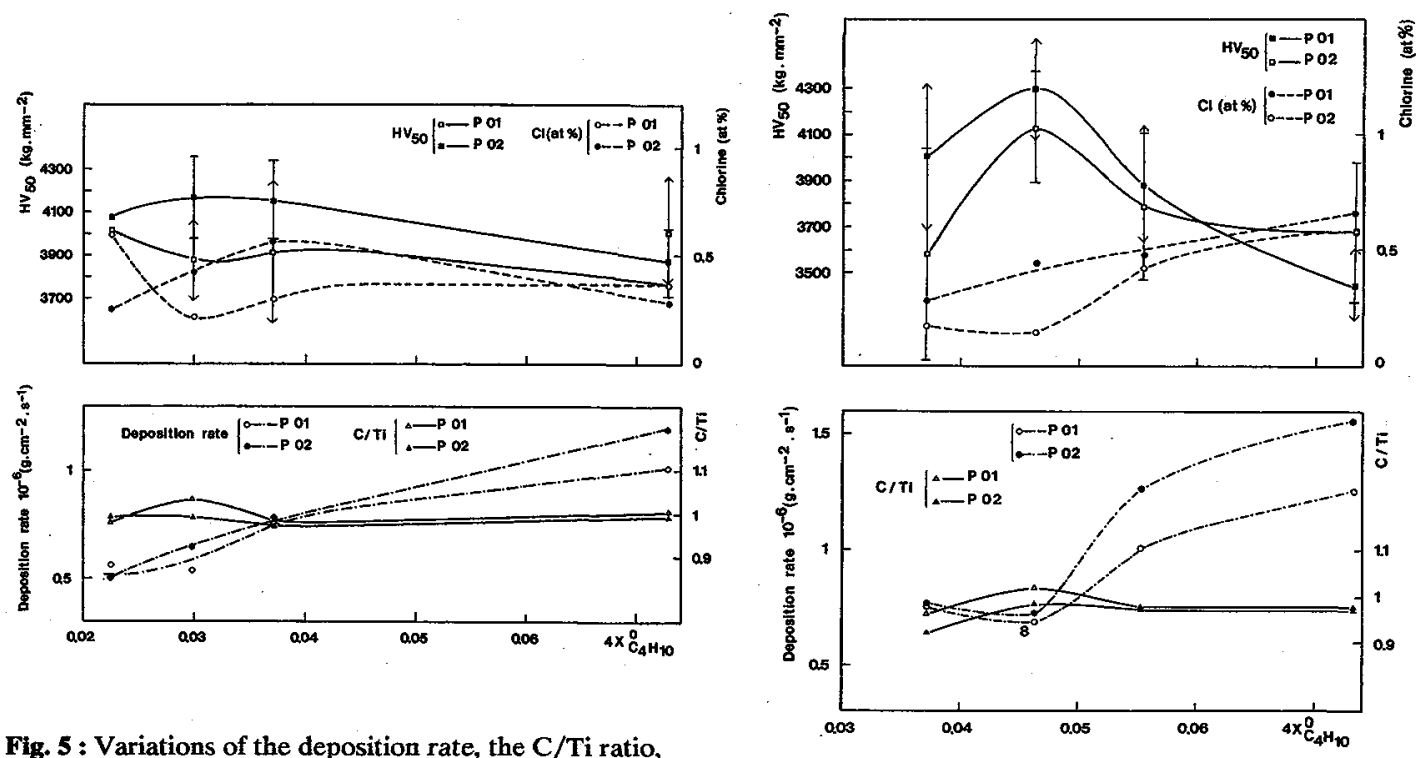

Fig. 5 : Variations of the deposition rate, the C/Ti ratio, the $\mathrm{Cl}$ content and the microhardness with the inlet butane concentration $\left(\mathrm{X}_{\mathrm{TiCl}_{3} .}^{\mathrm{O}} / 4 \mathrm{X}_{\mathrm{C}_{4} \mathrm{H}_{10}}^{\mathrm{O}}=1 / 4, \mathrm{~T}=850^{\circ} \mathrm{C}\right.$, $\mathbf{P}=5.33 \times 10^{3} \mathrm{~Pa}$ ).

Fig. 6 : Variations of the deposition rate, the $\mathrm{C} / \mathrm{Ti}$ ratio, the $\mathrm{Cl}$ content and the microhardness with the inlet butane concentration $\left(\mathrm{X}_{\mathrm{TiCl}_{3},}^{\mathrm{O}} / 4 \mathrm{X}_{\mathrm{C}_{4} \mathrm{H}_{10} \mathrm{O}}=1 / 5, \mathrm{~T}=850^{\circ} \mathrm{C}\right.$, $P=5.33 \times 10^{3} \mathrm{~Pa}$ ).

The above variations are more pronounced for $\mathrm{X}_{\mathrm{Ti}}^{0} / \mathrm{X}_{\mathrm{C}}^{0}=1 / 5$ as is shown in Figure 6 . Especially a decrease of the microhardness can be noticed when the Cl content exceeds 0.5 at $\%$. In all cases the microhardnesses of coatings deposited on carbides is lower than the corresponding coatings deposited on steel substrates. This observation can be attributed to two phenomena :

- (i) The grain size is always slightly larger for coatings deposited on carbides as compared to steel substrates although the grain size still is very small as compared to that of coatings deposited at $1000^{\circ} \mathrm{C}$.

- (ii) The coefficient of thermal expansion of $\mathrm{TiC}\left(7.5 \times 10^{-6}{ }^{\circ} \mathrm{C}^{-1}\right)$ is much smaller than that of steel $\left(\simeq 12 \times 10^{-6}{ }^{\circ} \mathrm{C}^{-1}\right)$, but larger than the thermal coefficient of cemented carbides $(\simeq(4-6) \mathrm{x}$ $\left.10^{-6}{ }^{\circ} \mathrm{C}^{-1}\right)$. The effect of compressive stresses observed on steel is suppressed. The relaxation of the tensile stress by cracks in the deposit particularly on pure WC/Co substrates results in a weakening of the actual increase of the microhardness due to the grain refinement on cemented carbides (600 - $1000 \mathrm{~kg} \cdot \mathrm{mm}^{-2}$ more than for conventional CVD TiC). 
The performance of a coating does not only depend on its microhardness but also on its adherence to the substrate. A scratch test was carried out on various samples coated with a 6 - 8 $\mu \mathrm{m}$ TiC under the conditions shown in Figures 5 and 8 The acoustic emission signals recorded during the scratch test of three typical samples, are shown in Figure 7. Although the samples a and b showed equal microhardness $\left(4000 \mathrm{~kg} \cdot \mathrm{mm}^{-2}\right)$, their adherence to the substrate appears to be quite different. This can also be seen in the micrographs in Figure 8 where the breaking modes of the two samples are demonstrated.

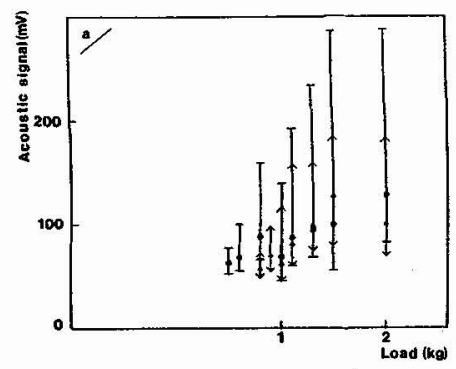

Fig. 7 : Acoustic emission recorded during a scratch test at different load on three samples:
a) $\mathrm{X}_{\mathrm{TiCl}_{3 .}}^{0}=0.95 \times 10^{-2}, 4 \mathrm{X}_{\mathrm{C}_{4} \mathrm{H}_{10}}=3.8 \times 10^{-2}$,
$\mathrm{T}=850^{\circ} \mathrm{C}, \mathrm{P}=5.33 \times 10^{3} \mathrm{~Pa}, \mathrm{Hv}_{50}=3900 \pm 320 \mathrm{~kg} \cdot \mathrm{mm}^{-2}$.
b) $\mathrm{X}_{\mathrm{TiCl}_{3 .}}^{\mathrm{O}}=1.3 \times 10^{-2}, 4 \mathrm{X}_{\mathrm{C}_{4} \mathrm{H}_{10}}^{\mathrm{C}}=5.5 \times 10^{-2}$,
$\mathrm{T}=850^{\circ} \mathrm{C}, \mathrm{P}=5.33 \times 10^{3} \mathrm{~Pa}, \mathrm{Hv}_{50}=4300 \pm 360 \mathrm{~kg} \cdot \mathrm{mm}^{-2}$ ).
c) classical $\mathrm{TiC}$ coating deposited on cemented carbide at $1000^{\circ} \mathrm{C}$.

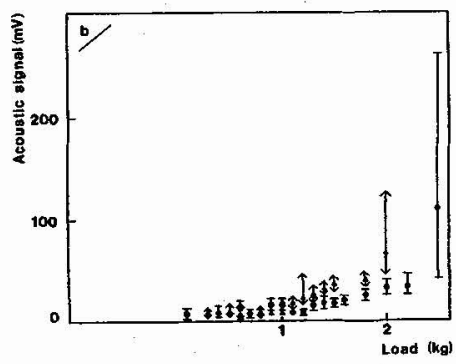

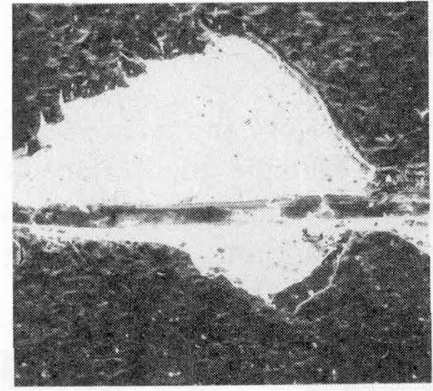

a

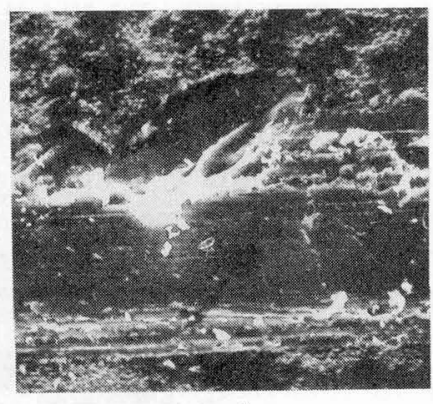

b

Fig. 8 : (a - b) Scratch morphologies, corresponding respectively to scratch tests of figure $7 a$ and $b$, for loads higher than the critical ones.
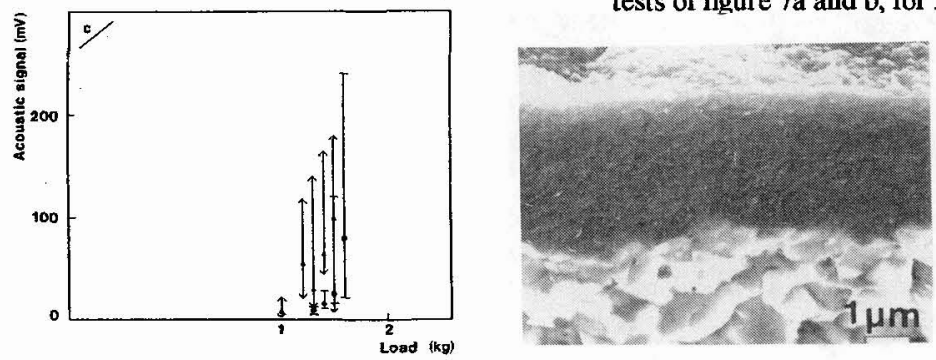

Fig. 9: Well-adhering fine-grained $\mathrm{TiC}$ coating without porosity at the interface with a cemented carbide, shown on a fractured cross-section.

From the above results it is clear that it is quite possible to deposit both adherent and hard TiC coatings under conditions outlined previously (Figure 9). This layer when utilized alone for a milling test did not give better results than commercial $\mathrm{TiC} / \mathrm{TiN}$ bilayer high temperature coatings. However the commercial ones were TiN coated which might be an important difference since the chip from the steel work material has different welding properties to TiC and TiN.

\section{3 - TITANIUM NITRIDE DEPOSITION AT MODERATE TEMPERATURE.}

As shown previously [3-4] titanium nitride layers can also be deposited from titanium subchlorides. However a reactant of low stability such as $\mathrm{NH}_{3}$ could not be used under similar conditions as those employed for the titanium carbide process. A homogeneous reaction between ammonia and the chlorides was always noticed. A mixture of $\mathrm{NH}_{3}$ and $\mathrm{N}_{2}$ with concentrations of 
$\mathrm{NH}_{3}$ as low as $1 \%$ resulted in very porous deposition materials for the total process pressure equal or larger than 10 torr. To avoid the use of very different deposition conditions and experimental set-up, in particular the pumping system, the chemical mixture was chosen to be $\mathrm{TiCl}_{3}, \mathrm{H}_{2}, \mathrm{~N}_{2}$, and the deposition temperature was fixed at $850^{\circ} \mathrm{C}$. With this chemical system and with the stability of nitrogen, it is clear that high supersaturation at the gas-solid interface could not be obtained, as in the case of the TiC deposition. Consequently, the same degree of grain refinement could not be reached.

The optimization of the titanium nitride deposition process was not carried out in such a detail as that for the carbide, but the following properties were focused on :

(i) A near stoichiometric $\mathrm{Ti} / \mathrm{N}$ composition and a minimization of the chlorine incorporation, as shown in another paper [4].

(ii) A microhardness of the coating being at least equal to that reported for the conventional process from $\mathrm{TiCl}_{4}, \mathrm{~N}_{2}$, and $\mathrm{H}_{2}$. Hardness values up to $2500 \mathrm{~kg} \cdot \mathrm{mm}^{-2}$ under $25 \mathrm{~g}$ load have been found for the best deposition conditions.

(iii) Optimization of coating morphology and microstructure in terms of grain size, equiaxed grains and surface morphology. For example the surface morphology and columnar growth observed on the same sample as shown in Figure 10, could be avoided. This morphology leads to a maximum arithmetic roughness larger than $6 \mu \mathrm{m}$ and an average arithmetic roughness of appr 1.5 $\mu \mathrm{m}$ as shown in Figure 11 for $\mathrm{X}_{\mathrm{T} \text { i }}^{\circ}$ nearly equal to 0.06 .

a

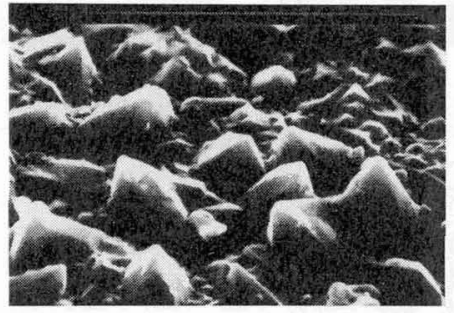

b

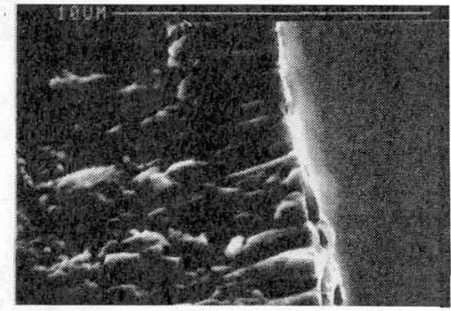

Fig. 10 : a) Surface morphology with large grains of a TiN coating deposited under poor conditions $\left(\mathrm{X}^{0} \mathrm{TiCl}_{3}=0.6 \times 10^{-2}, 2 \mathrm{X}^{0} \mathrm{~N}_{2}=0.64, \mathrm{~T}=850^{\circ} \mathrm{C}, \mathrm{P}=5.33 \times 10^{3} \mathrm{~Pa}\right)$.

b) Fractured cross-section showing a TiN columnar growth observed on the same sample.

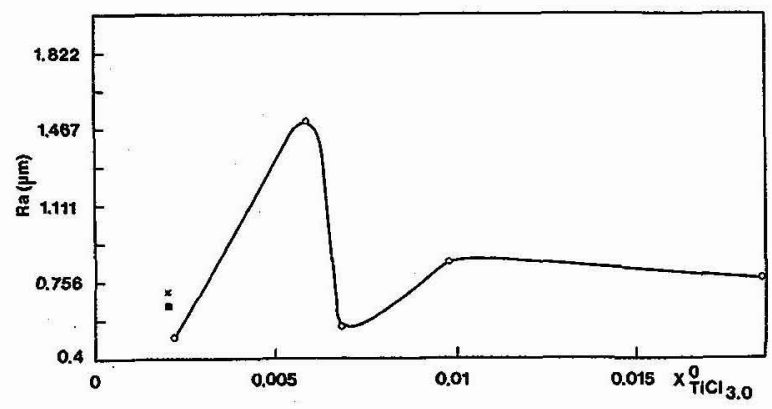

Fig. 11 : Average arithmetic roughness variations as a function of the inlet titanium subchlorides concentration $\left(2 \mathrm{X}_{\mathrm{N}_{2}}=\right.$ $\left.0.6, \mathrm{~T}=850^{\circ} \mathrm{C}, \mathrm{P}=5.33 \times 10^{3} \mathrm{~Pa}\right)$.

The other morphologies with finer grains are shown below with the results of the investigations of the bilayer TiC/TiN coatings. It can be noted here that the measured friction 
coefficient between the TiN coating and a 35CD4 steel followed the variations of the roughness for similar $\mathrm{Ti} / \mathrm{N}$ composition and $\mathrm{Cl}$ incorporation.

The conditions for $\mathrm{TiN}$ deposition were thus chosen to provide the best compromise regarding the previous points, with $X_{T i}^{0} \leq 0.045$ in the inlet gas phase, and the other parameters corresponding to Figure 11.

\section{4 - INVESTIGATIONS OF THE TIC/TIN BILAYER COATING :}

Experiments have been conducted on 530 and 565 SANDVIK substrates. Figure 12 shows polished cross section of substrate 565 . Only a few small dots of eta-phase can be detected under a $4.5 \mu \mathrm{m} \mathrm{TiC} / 1.5 \mu \mathrm{m}$. TiN coating. Substrate 530 shows no eta-phase. These results are to be expected due to the moderate deposition temperature. The surface morphology was optimized as shown in Figure 13 but it can differ slightly between experiments. The grains, of size in the range $0.2-0.7 \mu \mathrm{m}$, can form quite large agglomerates which lead to a higher roughness of the surface. Fractured cross-sections on both 530 and 565 substrates show a close packed-fine grained equiaxed TiC-coating, then a more porous zone with coarser TiN grains. It must be noted that the layers were deposited in two separate deposition experiments.

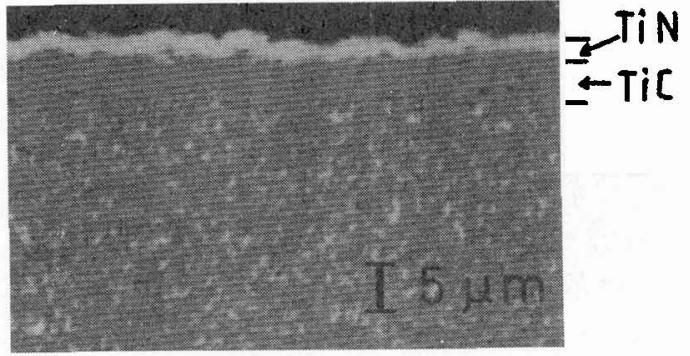

Fig. 12 : Polished cross-section of a bilayer TiC/TiN coating deposited on substrate 565 .

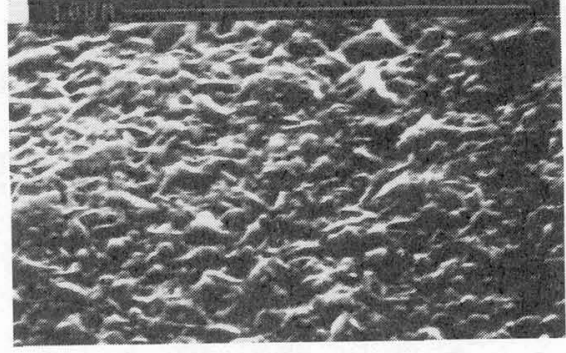

Fig. 13 : One example of a relatively fine-grained surface morphology of TiN.

A toughness test was performed on substrate 565 and $\mathrm{TiC} / \mathrm{TiN}$ conventional high temperature CVD coatings $\left(\simeq 1000^{\circ} \mathrm{C}\right)$ were used as reference. All but one of these last inserts fractured at half cutting length. The main part of the moderate temperature TiC/TiN coating has not fractured when the milling test was stopped (Fig. 14).

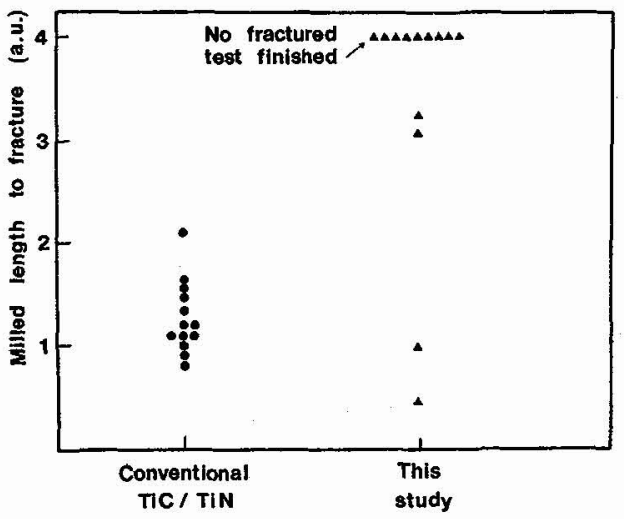

Fig. 14 : Toughness test on substrate 565 compared to a conventional high temperature CVD coating. 


\section{5 - ACKNOWLEDGMENTS}

The authors gratefully acknowledge AB Sandvik Coromant Stockholm Sweden for financial support, for supplying the cemented carbide specimens and carrying out the milling test ; also for the release of the data used in the thesis of B. Drouin and also reported here. Comments and encouragement from Dr Mats Sjöstrand are greatly appreciated.

\section{REFERENCES :}

/1/PITON J.P, LADOUCE B. and VANDENBULCKE L., Proc. of the 6th Europ. Conf. on CVD, R. Porat Ed., Iscar Ltd, P.O.B. 34, Nahariya 22100 Israel ; Jerusalem, Israel, March-April $1987,120$.

/2/DROUIN-LADOUCE B., PITON J.P. and VANDENBULCKE L., Proc. of the 7th Europ. Conf. on CVD, M. Ducarroir, C. Bernard and L. Vandenbulcke Eds, J. de Physique, 50, Colloque C5, May 1989, 367.

/3/DROUIN-LADOUCE B., Thesis, Orléans, 1990.

/4/DROUIN-LADOUCE B., BERNARD C. and VANDENBULCKE L., To be published.

/5/PITON J.P., Thesis, Orléans, 1990.

/6/WILLIAMS W.S., LYE R.G., ML-TDR-64-25, Part I, Air Force Material Laboratory, Research and Technology Division, Air Force System Command, Wright Patterson A.F.B. Ohio.

/7/HINTERMANN H.E., GASS H., LINDSTROM J.N., Proc. of the 3rd Int. Conf. on CVD, F.A. Glaski Ed., The American Nuclear Society, 1972, 352.

/8/ROSER K., Proc. of the 8th Int. Conf. on CVD, J.M. Blocher Jr., G.E. Vuillard, G. Wahl, Eds, The Electrochem. Soc.

Pennington, N.J., 1981, 586.

/9/LEE C.W., CHUNG J.S., Ibid /8/, 540. 